\title{
経済性の観点に基づく電力系統内分散型電源の 最適導入計画
}

\begin{tabular}{|c|c|c|c|c|}
\hline 正 員 & 西 谷 & 健 & 一 & (北海道工大) \\
\hline 正 員 & 北 & 裕 & 幸 & (北海道大) \\
\hline E 員 & 長谷川 & & 沾 & (北海道大) \\
\hline 員 & 芳 賀 & & 浩 & (JR 北海道) \\
\hline 員 & 皆 & & 志 & (北海道電力) \\
\hline 会 ! & 島 & & 二 & (北海道電力) \\
\hline$\hat{\theta}$ & 中 & & & (北海道電力) \\
\hline
\end{tabular}

Optimal Planning for Introducing Dispersed Generating Sources in Power Systems Based on an Economical Point of View

Ken-ichi Nishiya, Member (Hokkaido Istitute of Technology), Hiroyuki Kita, Member, Jun Hasegawa, Member (Hokkaido University), Yoshihiro Haga, Member (Hokkaido Railway Co.), Kazushi Minagawa, Member, Kenji Simazu, Non-member, Hideo Nakamura, Non-member (Hokkaido Electric Power Co.)

This paper discusses optimal planning problems for dispersed generating sources so as to give a guideline of their introduction to power systems. First, a recursive method is developed from the viewpoint of supplying electric power only, in which solutions for one unit are superposed. The computational loads are decreased by selecting alternatives of busses based on the so-called penalty factor. However, for effective utilization of dispersed generating sources, it is indispensable to consider their thermal merits in addition to electric power. After applying the Khun-Tucker theory to the optimal dispatching problem including boiler fuel costs, thermal values of the dispersed generating units are evaluated quantitatively. Finally, the above-mentioned technique for the optimal planning is also effective basically and is extended into this case. The validity of the proposed algorithms are demonstrated using a real-scale model system.

キーワード：電力系統，分散型電源，熱電併給，最適導入計画，経済負荷配分

\section{1. まえがき}

近年の電力系統に扔いては，負荷率の悪化に伴う設備利 用率の低下傾向が続いており，一方，化石燃料の使用増加 が地球環境に及ほす影響も世界的に関心を集めている。こ れらの問題を解決するためには，省エネルギーも同時に実 現しうる太陽電池, 燃料電池などの分散型電源, および新 型二次電池, SMESなどの電力䀰蔵設備の電力系統への 導入が有効であり，様々な側面からの研究が各方面で行わ れている(1)(2)。しかしそれらの無秩序な導入は，系統設備 の運用や計画の障害となり，結局省エネルギー効果，更に は系統全体の経済性をも損なう結果となりかねない。効率 的な電力システム構成のためには, 計画段階における配 置・運用に関する検討が重要な課題である。
本論文では, 分散型電源に着目した最適導入計画を検 討，評価することを目的とし，まず第 2 章において，電力 供給のみを対象とした分散型電源配置計画問題について論 述する。また，燃料電池のような熱・電併給分散型電源の 尊入を考える場合には，電気エネルギー供給によるメリッ 卜に加え，熱エネルギー供給の価值を何らかのかたちで評 価したうえ，配置点を決定する必要がある。そこで，第 3 章では電力供給に加え, 熱供給をも考慮した最適導入計画 について詳述する。第 4 章では, 提案手法を実規模モデル 系統に適用し, 分散型電源導入に対する経済性の評価を行 っている。

\section{2. 電力供給の観点からの配置点の決定}

\section{〈2・1〉提案手法の概要 分散型電源は一般に負荷端}


に導入・設備されるが, その際, 負荷率の改善, 安定度お よび信頼度の向上など，導入に期待するメリットにより最 適な配置方策は異なる。本研究では, 現運用システムに分 散型電源を導入した際の経済評価，また平常運用状態での 経済評価の観点に立ち, 燃料費の抑制, 送電損失の軽減を 定量的に考慮したうえで，分散型電源導入に指針を与える 手法を開発している。提案手法は，既に検討がなされてい る電力貯蔵システムを対象としたアルゴリズム(3) と同樣, 1 台ずつ逐次配置を決定する近似解法である。

いま，計画問題ではあるが他の諸設備の計画は確定して いるものとして, それらの軽減費用を考えなければ, 最適 配置の決定は，火力発電所の総燃料費，および分散型電源 費用の最小化問題と考えることができる。更に，ある時間 带において, 各発電所分担負荷が等 $\lambda$ 則に基づき経済配 分され，発電機母線での増分送電損失を一定と仮定できれ ば，導入により総燃料費を最小にすることは，総発電量を 最小（送電損失を最小）とすることに浪かならない。結 局, 分散型電源 1 台の最適配置点は, 系統内の全母線に 各々配置した場合の, 対象期間内における総コストを算 定, 比較し, その值が最小となる母線を決定すればよいこ ととなる。

複数台の導入を考える際には，導入するニニットすべて を同時に配置した場合の導入効果を評価すべきであるが， 配置パターンの組合せの数は, 母線数の増加に伴い指数関 数的に増大する（導入台数 $x$ 台，母線数 $n$ の場合で $n^{x}$ 通り)。従って，すべてのパターンに対するコスト計算は 害用的ではない。本手法では，複数台の尔散型電源導入を 対象とした問題に対し，ユニットを 1 台ずつ導入し，既に 導入されているユニットの出力は固定して考えるという近 似手法を用いることとした。従って, 複数台の導入を 1 台 ずつの逐次計算の重ね合せとすることが可能となり，計算 回数も負荷が一定であれば，導入台数と同じ回数でよいこ とになる。具体的なアルゴリズムを，図1に示している。 系統総燃料賈は，経済性を追求することを目的とした送電 損失を含む経済負荷配分手法 ${ }^{(4)} に$ 基づき，火力発電所の 出力を等 $\lambda$ 法で決定することにより算定している。ただ し，導入した分散型電源が必ず連用されるとは限らず，こ こでは，高負荷時間帯から計算を実行し，分散電源出力が 下限值に一致する時間带まで運用することとしている。ま た，本手法では配置候補母線を選択し計算負担の軽減を図 つているが，この点については次節に詳述する。

〈2・2〉配置候補母線の選択 ${ }^{(5)}$ 前節に提案したアル ゴリズムで最適配置点を決定する際, 臀密には全地点への 配置に対しコストを算定しなければならないが，その場 合，配置対象地点数と同じ回数のコスト計算が必要とな る。実系統では配置の対象となる母線は数多く存在し，全 時間帯ですべての母線を考慮することは，かなりの計算負 担となる。

ここで, 分散型電源の任意の運用状態, ある時間断面を 考える。分散型電源の出力が $\Delta P_{c}(>0)$ だけ増加し, これ

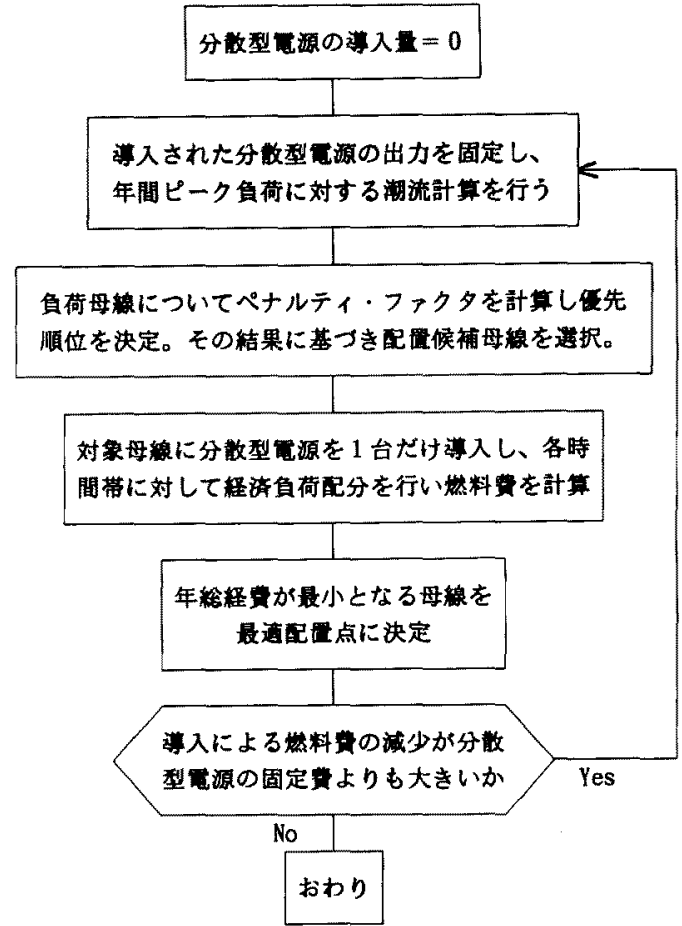

図 1 電力供給の観点からの導入決定手法

Fig. 1. An algorithm to decide the introduction.

表 1 記号の定義

Table 1. List of symbols.

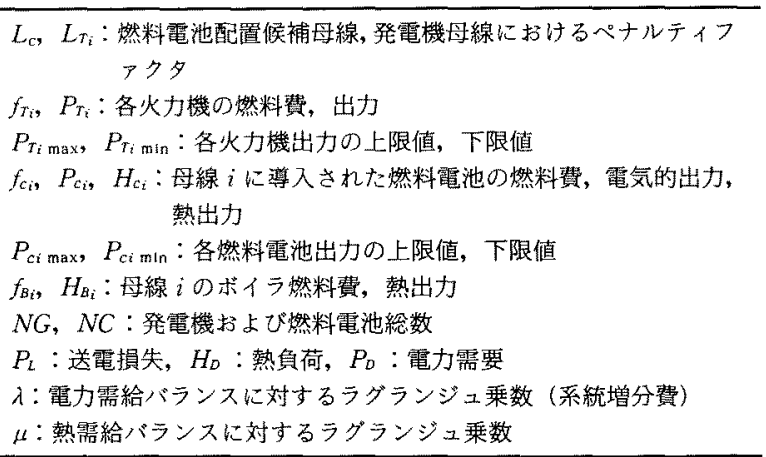

に伴い各発電機の出力が $\Delta P_{T i}(>0)$ だけ減少するものとす ると, 需給平衡条件より次式が成立する。

$$
\Delta P_{c}=L_{c} \Sigma\left(\Delta P_{T_{i}} / L_{T_{i}}\right)
$$

次に, 分散型電源の出力増加にメリットがあるのは, 次式 が満たされる場合である。

$$
\sum \Delta P_{T i} \frac{d f_{T i}}{d P_{T i}}>\frac{d f_{c}}{d P_{c}} \Delta P_{c}
$$

発電機出力が経済負荷配分されているならば，上式は等 $\lambda$ 則，および(1)式より以下のように変形される「具体的な 導出過程は, 後で述べる(18)式のそれと同様であり, 咩細 は付録を参照されたい]。

$$
\left(\lambda / L_{c}\right)>\left(d f_{c} / d P_{c}\right)
$$

結局，上式が成立するときのみ分散型電源の運転にメリ ットが生じることから，（3）式を運用成立条件式と呼ぶ。 同式に抽いて，扔よび右辺の值は母線によらず一定であ る。従って， $L_{c}$ の值が小さいほど, 運用成立条件式が満 
足されやすく，運転のメリットが大きいことになる。本手 法では, ペナルティファクタの值が小さい順に母線に優先 順位を与えることで検討対象をあらかじめ限定し，選択さ れた母線に対してのみコスト計算を行うこととする。優先 順位決定の際には, 導入メリットが最大と考元られる年負 荷ピーク時のペナルティファクタの值を用いている。実際 には, 各時間断面において負荷レベルや系統状態が変化す るため, ペナルティファクタによる優先順位も異なるはず である。しかし提案アルゴリズムでは，優先順位に基づき 導入メリットが明らかに小さい母線を検討対象から除外す るだけであり，実際の配置点は，コストを算定，比較する ことで決定している。以上により, 実規模系統に执いて最 適配置点を少ない計算負担で決定することが可能となっ た。

\section{3. 熱・電併給分散型電源の最適導入計画}

〈3・1〉熱併給を考慮した最適運用方策燃料電池の ような熱・電併給分散型電源を対象とする場合，熱供給の 価值を何らかのかたちで評価しなりればならない。そこで， 熱供給を考慮する場合の配置決定に先立ち, 本節では運用 問題に関して, 総燃料費最小化問題の定式化を行い検討を 加える。ボイラは熱併給システムを構成するという立場か ら, 然料電池の熱出力でまかなえない容量分を補うもので ある。このような最適化問題は, 次式で定式化される。

$$
\underset{(P T, P C, H B)}{\operatorname{Min}} F=\sum_{j=1}^{N G} f_{T J}\left(P_{T j}\right)+\sum_{i=1}^{N C} f_{c i}\left(P_{C i}\right)+\sum_{i=1}^{N C} f_{B i}\left(H_{B i}\right)
$$

subj. to

$$
\begin{array}{rr}
P_{D}+P_{L}-\sum_{j=1}^{N G} P_{T j}-\sum_{i=1}^{N C} P_{C i}=0 \\
H_{C i}\left(P_{C i}\right)+H_{B i}-H_{D i} \geqq 0 & (i=1, \cdots, N C) \\
P_{T j \min } \leqq P_{T j} \leqq P_{T j \max } & (j=1, \cdots, N G) \\
P_{C i \min } \leqq P_{C i} \leqq P_{C i \max } & (i=1, \cdots, N C) \\
H_{B i} \geqq 0 & (i=1, \cdots, N C)
\end{array}
$$

上式中, 制約条件の最初の 2 本は, それぞれ, 電力需給バ ランスと熱供給制約条件である。熱供給に関しては，他地 域間の熱エネルギー融通を考元ず，また各地点において燃 料電池からの熱出力が熱負荷を上回わることも許してい る。

さて，上述の問題に対してラグランジェ関数を構成し， Kuhn-Tucker 条件を適用する(ただし，上下幔制約に関 する項は省略)と, 最適解は次の一連の式を渾足しなけれ ばならない。

$$
\begin{aligned}
& \frac{\partial L}{\partial P_{T j}}=\frac{d f_{T_{j}}}{d P_{T_{j}}}-\lambda\left(1-\frac{\partial P_{L}}{\partial P_{r j}}\right)=0 \\
& \frac{\partial L}{\partial P_{c i}}=\frac{d f_{c i}}{d P_{c i}}-\lambda\left(1-\frac{\partial P_{L}}{\partial P_{c i}}\right)-\mu_{i} \frac{d H_{c i}}{d P_{c i}}=0 \\
& \frac{\partial L}{\partial H_{B}}=\frac{d f_{B i}}{d H_{B i}}-\mu_{i} \geqq 0 \\
& \left(\frac{d f_{B i}}{d H_{B i}}-\mu_{i}\right) H_{B i}=0
\end{aligned}
$$

$$
\begin{aligned}
& H_{D i}-H_{c i}\left(P_{c i}\right)-H_{B i} \leqq 0 \\
& \mu_{i}\left(H_{D i}-H_{c i}\left(P_{C i}\right)-H_{B i}\right)=0 \\
& \mu_{i} \geqq 0, H_{B i} \geqq 0 \\
& P_{c i \max } \geqq P_{c i} \geqq P_{c i \min } \\
& P_{T j \max } \geqq P_{T j} \geqq P_{T j \min }
\end{aligned}
$$

ここで（（5)式扔よび（6)式から次式が得られる。

$$
\begin{aligned}
\lambda\left(1-\frac{\partial P_{L}}{\partial P_{T j}}\right) & =\frac{d f_{T j}}{d P_{T j}} \cdots \ldots \ldots \ldots \ldots . . . . . . \\
\lambda\left(1-\frac{\partial P_{L}}{\partial P_{c i}}\right) & =\frac{d f_{c i}}{d P_{c i}}-\mu_{i} \frac{d H_{c i}}{d P_{c i}} \\
& =\frac{d}{d P_{c i}}\left(f_{c i}-\mu_{i} H_{c i}\right)
\end{aligned}
$$

(12)式と(13)式を比較すると，(13)式の $\left(f_{c i}-\mu_{i} H_{c i}\right)$ が $f_{T_{j}}($ ( $/ \mathrm{h})$ と同じ単位をもっていることが理解され，同式 の（）内を “熱等価換算コスト”と定義する。熱等価換算 コストは，電力発生のためのコストを意味する第 1 項か ら，第 2 項の熱メリットを隇じた形となっている。更に， $\mu_{i} H_{c i}$ が $($ 円 $/ \mathrm{h})$ の単位をもつことから， $\mu_{i}$ の単位が [円/Mcalh]であることがわかる。的は燃料電池の各運 用状態にお汀る排熱の洒值を表しているので，この係数は “熱等価換算係数” と定義される。虫た，(7)，(11)式加 ら $\mu_{i}$ の值は,

$$
0 \leqq \mu_{i} \leqq\left(d f_{B i} / d H_{B i}\right)
$$

となるが， $\mu_{i}$ の值の物理的意味は，(5)〜(11) 式から得 られる以下の三つの最適運用状態で説明される。

（1）熱需給バランスがとれている場合燃料電池か らの熱出力とボイラで熱需要をまかなう場合である。この 場合, 熱等価換算係数 $\mu_{i}$ の值は

$$
\mu_{i}=d f_{B i} / d H_{B i}
$$

となる。(14)式より $\mu_{i}$ の值が最大，つまり熱メりットが 最大となっていることがわかる。燃料電池の増分燃料費 は，(13)式右辺のように熱等価換算係数を含むかたちで表 され，燃料電池出力はこの修正増分燃料費を用い，火力機 とともに等 $\lambda$ 則により決定される。燃料電池の熱出力は, 熱需要よりも小さくならなければならない。

（2）燃料電池からの熱出力が熱需要に一致する場合 燃料電池の熱出力が熱需要に一致することから，ボイラ 出力は零である。このケースに扮いても(5)，(6)式か ら，等 $\lambda$ 則に基づき燃料電池の電気的出力が算出される が, その結果燃料電池の熱出力が熱需要と一致するように 熱等価換算係数 $\mu_{i}$ が決定される。

（3）燃料電池からの発生熱が熱需要を上回わる場合

燃料電池からの熱出力が熱需要を超える運転のケースて あり，ボイラは運転されず熱等価換算係数 $\mu_{i}$ の値は零と なる。つまり，熱的メリットのない状態である。各発電 機, 燃料電池の出力は, 従来どちりの等増分燃料費則によ り決定される。

〈3-2〉熱併給を考慮した最適配置点決定手法 第 2 章と同様, 分散型電源の配置注年間の様々な負荷パターン を考慮し決定されなりればならない。各時間帯で，前節で 導出した熱併給分散型電源の最適運用方策に基づき, 各工 
ニットの出力を決定することができれば，年間の系統総燃 料費が算定可能となる。ここで, 各火力機, 扔よび燃料電 池の出力は，(12)式抢よび(13) 式で示される増分燃料費を 用い決定されるが，この場合，(13）式に含まれている熱等 価換算係数 $\mu_{i}$ の值が必要となる。しかし， $\mu_{i}$ の值は前節 の (1) ～(3) 項に分類されるように燃料電池の運用状態に よって異なるため, 各々の時間带に扔ける最適運用状態を 決定しなければ求められない。従って, 配置決定時には未 知であり正確な $\mu_{i}$ の值を用いた出力配分はできない。

前節 (1) 項のように, 熱負荷が燃料電池の熱供給量より も大きければ熱価值が最大 $\left(\mu=d f_{B i} / d H_{B i}\right)$ となることか ら, 熱負荷が大きいほど, 熱価值最大の状態で運転できる 可能性も高いと予想される。図 2 は，4 通りの熱負荷（実 線）に対し然料電池出力值に対応する のである。 $H_{c \max }$ が最大熱出力值であり, 燃料電池出力に かかわらず, 同図 (1)では $\mu_{i}$ が零となり (4)では $\mu_{i}$ が最 大となる。（2），(3)を比較すると，系統の影響により簡 単には判断できないが，（3）のほうが熱メリットが大きく なる可能性が高いことが容易に予想できる。そこで配置決 定の際には，

$$
\mu_{i}=\frac{(\text { 熱負荷 })}{(\text { 燃料電池最大熱出力 })} \times a
$$

と近似して出力を決定するものとする。ただし，上式にお ける(熱負荷) は燃料電池で供給可能な熱負荷， $a$ は $\mu_{i}$ の 最大值 $\left(\alpha=d f_{B i} / d H_{B i}\right)$ である。熱併給を考慮した分散型電 源の最適導入計画決定アルゴリズムを図 3 に示す。基本的 には，第 2 章で述べた決定手法と同様，経済負荷配分によ り総コストを算定・比較しコスト最小となる母線を決定し， 更に複数台の導入に対しても前章に扔ける手法と同様に扱 っている。また, 次節に詳述すると扝り, 候補母線の選択 により計算負担の軽減を図っている。なお，〈3・1〉節の定 式化も分散電源の並解列を決めるものではなく，その出力 が下限值に一致した時間帯では, 次のユニットが同じ母線 に配置されたとしても運用しないものとしている。

〈3・3〉 配置候補母線の選択法燃料電池の運用成立 条件を考えると，その出力增加にメリットが存在するの

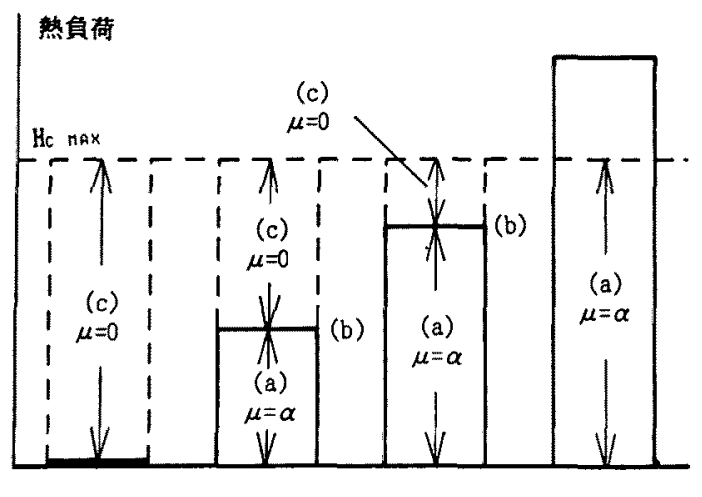

(1)

(2)

(3)

(4)

図 2 分散型電源最適運用状態

Fig. 2. Optimal operating condition.
は，次式が成立する場合である。

$$
\sum_{j=1}^{N G} \Delta P_{T_{j}} \frac{d f_{T_{j}}}{d P_{T_{j}}}>\frac{d f_{c}}{d P_{c}} \Delta P_{c}-\frac{d f_{B}}{d H_{B}} \Delta H_{B}
$$

また(17)式は等 $\lambda$ 則，拈よび電力需給平衡式により，次 式のように変形される(付録参照)。

$$
\beta=\frac{\lambda}{L_{c}}+\mu_{i} \frac{d H_{c}}{d P_{c}}>\frac{d f_{c}}{d P_{c}}
$$

上式が成立する場合のみ燃料電池の運転にメリットがあ り，前章同様，この式を熱供給を考慮した場合の，運用成 立条件式と呼ぶことにする。 $\beta$ の第 1 項が電気的メリッ 卜，第 2 項が熱的メリットを意味している。 $d H_{c} / d P_{c}$ ， $d f_{c} / d P_{c}$ の值仿，導入する燃料電池の仕様㲹よって決定さ れる值であり，定数と考えると左辺の值が大きいほど，通 用成立条件を満たす可能性が高く，また運転メリットも大 きいと考えられる。従って，この $\beta$ の値を指標として各 地点の優先順位を決定し, 評価対象母線を限定することが 可能となる。

ところで $\beta$ 算定の際には， $\mu_{i}$ の值が必要となる。ここ で最適運用方策を考えると，図４に示すと㧍り(1)面積が 大きいほど，全時間帯にわたり熱価值の高い状態で運転で きる可能性が高いこととなる。そこで(2)を高さ $H_{c \max }$ の長 方形の面積として，(1)/(2)の值を各地点での“熱有效利用 期待値 $\eta ” と し$, 更に $\mu$ の最大值 $\alpha$ を乗じた值 $\mu_{i}^{\prime}$ を, “各地点に扔ける熱等価換算係数” と定義することとする。

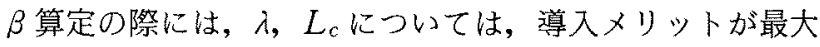
となると思われるピーク時の值を， $\mu$ の值としては各地点 に㧈ける $\mu_{i}^{\prime}$ の值を用いることとする。

〈3.4〉 ボイラ固定費の考慮 燃料電池導入に際し,

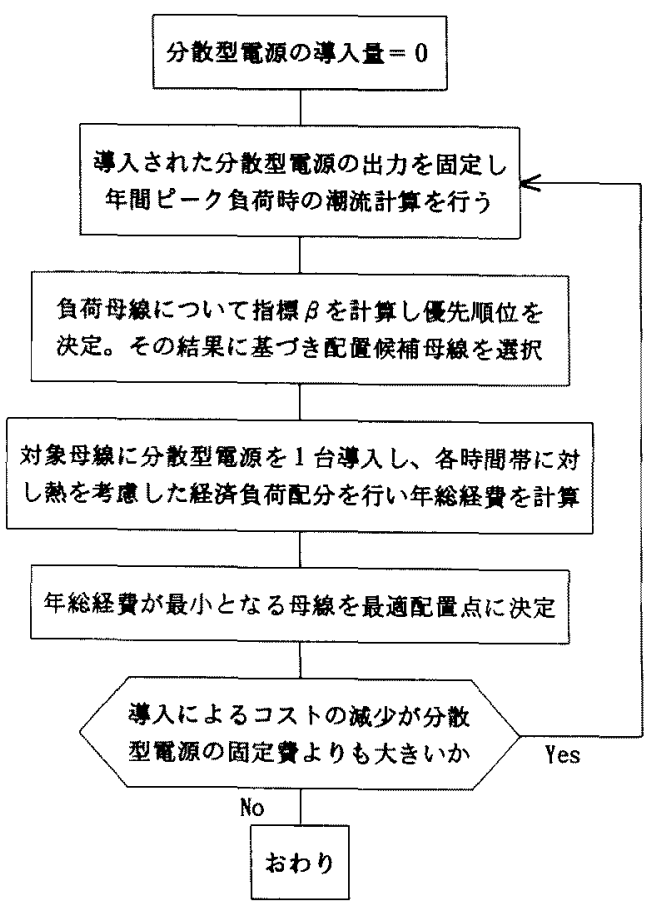

図 3 熱・電併給分散型電源の最適導入計画 Fig. 3. Optimal planning for introduction of cogenerating units. 


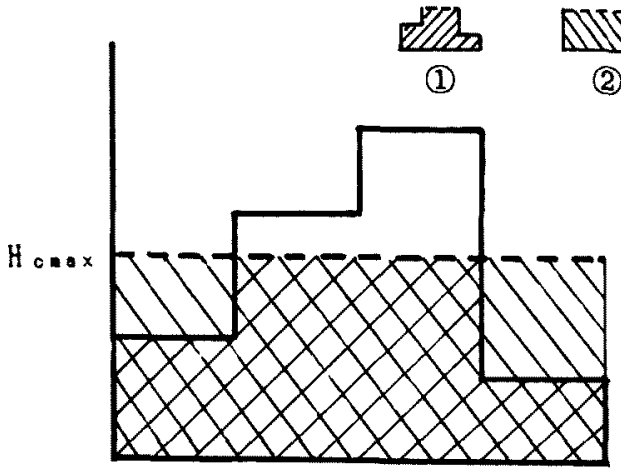

図 4 熱有効利用期待值

Fig. 4. Expected value of thermal utilization.

より現実的な経済性評価を行うためには熱供給代替手段と なるボイラの固定費を考虑する必要があるう。しかし，こ の固定費は年間を通して決定される值であり, 各時間帯で の運用定式化に含めることはできない。本研究において は，ボイラ固定費を

(ボイラ固定費)

$=[$ ボイラが負担する年間最大熱負荷 $(\mathrm{Mcal})]$

×[単位当たりのボイラ固定費 $($ 円 $/ \mathrm{Mcal}$ 年 $)]$

として算出する。このように考えると, 燃料電池出力がボ イラ固定費に影響することになる。

ところで, 提案手法では配置候補母線を選択し，その母 線に対してのみコスト算定を行っている。しかし，優先順 位決定の際に用いた $\beta$ にボイラ固定費は考慮されておら ず，この值を加えた後の総コストの順位が優先順位と同様 の結果になる保証はない。熱負荷ピーク時間帯で燃料電池 が部分負荷となる母線が存在する場合には, ボイラ固定費 の抑制分が小さく，他の選択されない母線で熱負荷ピーク 時間帯の燃料電池出力が最大值となっていれば, そちらの 母線が有利な場合も考えられる。この問題に対しては, 分 散型電源の容量は比較的小さく影響も少ないと考元られる ことから, 設定した選択母線数を增やすことで対応してい る。

\section{4. モデル系統への適用}

開発した電力供給の観点からの配置決定手法，および 熱・電併給分散型電源を対象とした導入計画手法を，図 5 に示す 9 機 46 母線実規模モデル系統に適用し, その有効 性を検討する。各地点では各々異なる負荷パターンを想定 している。更に，負荷パターンは 1 年間を 4 季節，1日を 4 時間帯に分割した計 16 時間断面を考光, 各断面内の負 荷は一定とした。また, 配置対象母線は，18，24，31，37 の二次変電所より負荷側とし，その部分の最大合計負荷は 約 $670 \mathrm{MW}$ である。分散型電源としては燃料電池を対象 とし, 燃料電池, ボイラの諸元を表 2 に示している。なお 燃料電池の燃料費は, $100 \mathrm{~kW}$ 定格程度のデータから出力 の二次関数とし, それらの並列接続によりユニットの総容 量を想定した。

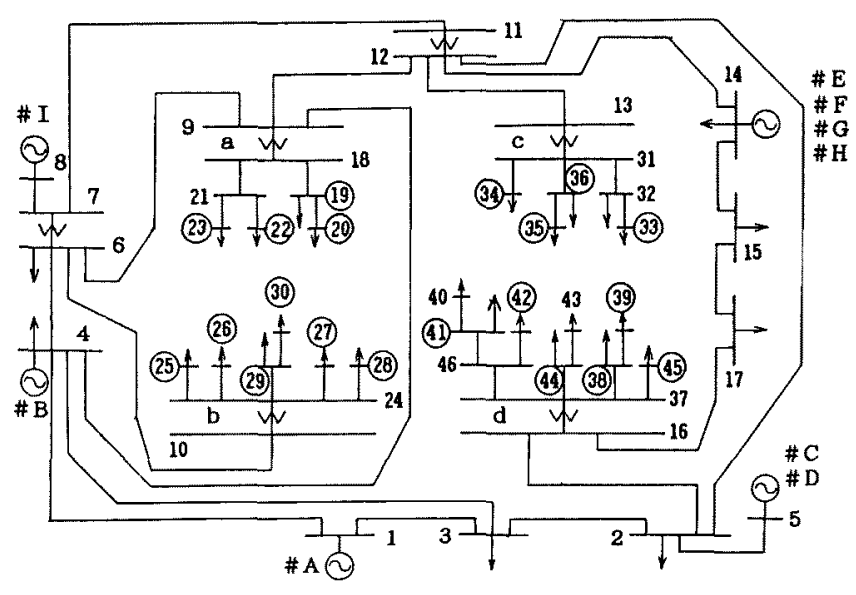

図 59 機 46 母線モデル系統

Fig. 5. 9-machines and 46-nodes model system.

表 2 使用したデータ

Table 2. Used data.

\begin{tabular}{|c|c|c|c|c|}
\hline \multirow{2}{*}{ 燃 } & 固 & 定 & 費 & 672.5 万円 $/ 100 \mathrm{~kW}$ - 年 \\
\hline & 燃 & 料 & 賮 & $20 \mathrm{~m} / \mathrm{kg}$ \\
\hline \multirow[t]{2}{*}{ 電 } & \multicolumn{3}{|c|}{ 電気・熱出力エネルギー比 } & $\frac{H_{c}}{P_{c}}=1$ \\
\hline & 使 & 燃 & 料 & メタノール \\
\hline \multirow{2}{*}{$\begin{array}{l}\text { 本 } \\
1 \\
5\end{array}$} & 固 & 定 & 費 & 58,000 円/Mcal • 年 \\
\hline & 燃 & 料 & 費 & 10 円/Mcal \\
\hline
\end{tabular}

表 3 数值計算結果

Table 3. Results of calculation.

\begin{tabular}{c|c|c}
\hline 儤先順位 & 母線番号 & 節約染 $(\%)$ \\
\hline 1 & 43 & -0.5741 \\
2 & 40 & -0.5743 \\
3 & 42 & -0.5742 \\
4 & 41 & -0.5743 \\
5 & 39 & -0.5742 \\
6 & 44 & -0.5742 \\
7 & 38 & -0.5743 \\
8 & 45 & -0.5744 \\
9 & 37 & -0.5744 \\
10 & 35 & -0.5762 \\
\hline
\end{tabular}

\section{〈4・1〉 配置母線の決定に関する試算結果}

(1) 電力供給の観点からの配置点の試算 第 2 章で 提案したアルゴリズムを，上述のモデルに適用した結果を 表 3 に示すが，優先順位と節約率（燃料電池導入により節 約されたコスト/導入前の総コスト）の大小関係はほほ一 致している。従って，優先順位に基づき数母線を選択すれ ば，その中に最適配置点が含まれている可能性が非常に高 く，提案手法が有効であることがわかる。しかしこの系統 では，節約率が真となり，つまり電気的メリットのみでは 分散型電源の導入が逆に総コストを引き上げてしまい，熱 的価值をも考慮しなければ導入が現実的とはならない結果 となった。

（2）熱併給を考慮した場合の試算 熱・電併給分散 型電源の配置決定に際し, 熱負荷が存在する地点は, 図 5 
表 4 熱併給を考慮した優先順位と節約率

Table 4. Priority and saving rates considering thermal merits.

\begin{tabular}{|c|c|c|c|}
\hline 儇先墕位 & 母線番号 & $\begin{array}{c}\text { 固定質考慮なし節約率 } \\
(\%)\end{array}$ & $\begin{array}{c}\text { 国定藚考慮節約率 } \\
(\%)\end{array}$ \\
\hline 1 & 42 & -0.2062 & 0.0339 \\
\hline 2 & 41 & -0.2063 & 0.0338 \\
\hline 3 & 44 & $-0.2061 \quad(1)$ & 0.0339 \\
\hline 4 & 38 & -0.2064 & 0.0336 \\
\hline 5 & 45 & -0.2066 & $0.0334 \quad$ (5) \\
\hline 6 & 39 & -0.2110 & 0.0068 (11) \\
\hline 7 & 22 & -0.2140 & $0.0249 \quad(6)$ \\
\hline 8 & 34 & -0.2145 & $0.0242(10)$ \\
\hline 9 & 20 & -0.2141 & $0.0248 \quad(7)$ \\
\hline 10 & 23 & -0.2142 & 0.0247 \\
\hline 11 & 19 & $-0.2143(10)$ & 0.0245 \\
\hline 12 & 35 & $-0.2172 \quad(12)$ & $-0.0003(12)$ \\
\hline 13 & 36 & $-0.2176(13)$ & $-0.0009(13)$ \\
\hline 14 & 25 & $-0.2186 \quad(14)$ & $-0.0020 \quad(14)$ \\
\hline 15 & 33 & -0.2640 (16) & $-0.0469(16)$ \\
\hline 16 & 27 & -0.2638 (15) & $-0.0466(15)$ \\
\hline 17 & 30 & -0.2641 & $-0.0470(17)$ \\
\hline 18 & 26 & $-0.2641 \quad(18)$ & $-0.0470(18)$ \\
\hline 19 & 29 & $-0.2642(19)$ & $-0.0470 \quad(19)$ \\
\hline 20 & 28 & $-0.2642(20)$ & $-0.0470 \quad(20)$ \\
\hline
\end{tabular}

（）内の数字は節約率の順位

中の丸印で示す 20 地点とした。また，熱負荷パターンと しては，恒常的な熱負荷をもつ住宅地域，昼間負荷が大き く夜間の負荷が小さい商業地域，この二つのパターンの中 間的負荷を有する混在地域，の三つを想定した。表 4 は， 表 3 と同様に，提案手法を用いて得られる配置母線の優先 順位と,その母線に然料電池(ユニット容量： $3 \mathrm{MW}$ ) 1 台導入したことによる実際の節約率(順位)とを，上位の母 線に対して表したものである。節約率は，ボイラ固定費を 考慮する場合としない場合に対して結果を示している。ボ イラ固定費を考慮しない場合，優先順位と実際の節約率順 位との間には，若干の相違が見られるもののかなり強い相 関があることがわかる。このことは，〈3・3〉節の指標 $\beta$ が 熱的メリットをも組み入れた配置母線の選択に有効である ことを意味している。実際のユニット設置母線の決定は， 総コストの算定に基づいており，上位 5 母線程度を対象と すれば 1 台目の導入に問題はない。また，ボイラ固定費を 考慮した場合においても，節約率の值そのものは異なって いるものの，節約率による順位はそれほど大きく変わらな い。特に，上位 5 母線については，考慮しない場合の結果 と全く同じ順位になっている。このことから，固定費を考 慮したことが候補母線選択法に与える影響は小さいものと 考えられ，〈3・4〉節で述べたような選択台数に融通性をも たせる手法が有効と考えられる。

\section{〈4・2〉パラメータ解析に基づく導入可能性評価}

簡便な手法による配置点の決定により，パラメータ変更 に伴う経済性評価が可能となったが，次に，熱負荷の大き さ扔よび燃料電池燃料費をパラメータとした場合の試算結 果を示す。配置母線は経済的メリットが最も大きい母線を

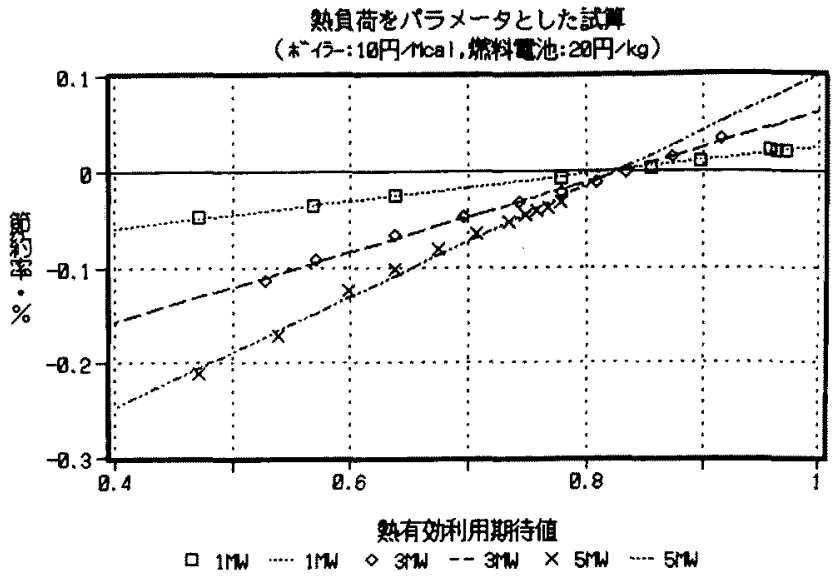

図 6 熱負荷の大きさを変化させた試算結果

Fig. 6. Saving rates versus thermal load.

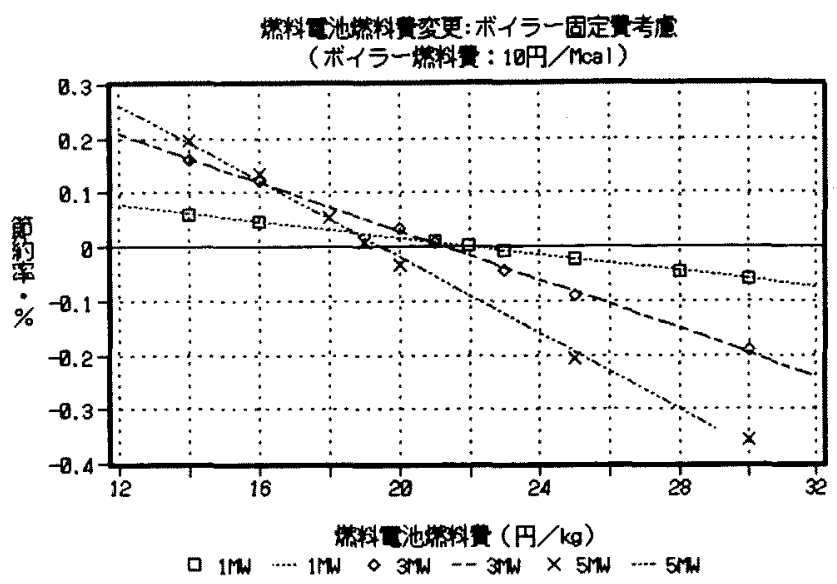

図 7 燃料電池燃料費を変化させた試算結果

Fig. 7. Saving rates versus fuel cost.

選択している。

最初に図 6 は, 熱負荷の形状は変えずに大きさだけを変 更した場合の節約率の推移を示したものである。燃料電池 のユニット容量によらず，第 3 章で定義した熱有効利用期

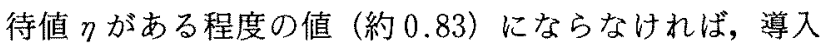
による経斉的メリットがないと判断されている。

次に図 7 は, 燃料電池の燃料費をパラメータとして試算 した結果を示している。然料費が $1 \mathrm{MW}$ ユニットで 22 円 $/ \mathrm{kg}, 3 \mathrm{MW}$ ユニットで約 21 円 $/ \mathrm{kg}, 5 \mathrm{MW}$ ユニットで 約 19 円 $/ \mathrm{kg}$ の場合それぞれ節約率が零となっている。従 って, 想定した燃料電池扔よびボイラの固定費の下で, こ のモデル系統への導入を考える際には，これらの燃料電池 燃料費よりも安くならなければ導入は難しいと推測され る。また，ユニット容量が変わると，燃料費の変更に伴う 節約率の変化の傾きが異なることがわかる。このことは， 燃料電池燃料費によって, 導入が有利な（節約率が大き い）ユニット容量が異なることを意味している。想定した データに扔いては，燃料電池燃料費が $21 〜 22$ 円 $/ \mathrm{kg}$ の場 合には $1 \mathrm{MW}, 16 \sim 21$ 円 $/ \mathrm{kg}$ の場合には $3 \mathrm{MW}, 16$ 円/ $\mathrm{kg}$ 以下では $5 \mathrm{MW}$ ユニットの導入が最も有利であること が予想される。 
表 5 容量変更に伴う最適配置の結果

Table 5. Results of optimal allocation.

\begin{tabular}{|c|c|c|c|c|}
\hline 母線番号 & $1 \mathrm{MW}$ (台) & $2 \mathrm{MW}$ (台) & $3 \mathrm{MW}$ (台) & $4 \mathrm{MW}$ (台) \\
\hline 19. 住宅地域 & 2 & 1 & 1 & 1 \\
\hline 20, 住宅地域 & 2 & 1 & 1 & 1 \\
\hline 22. 住宅地域 & 2 & 1 & 1 & 1 \\
\hline 23. 住宅地域 & 2 & 1 & 1 & 1 \\
\hline 25. 混在地域 & 2 & 1 & 1 & 0 \\
\hline 26. 商業地域 & 1 & 1 & 0 & 0 \\
\hline 27. 商業地域 & 1 & 1 & 0 & 0 \\
\hline 28. 商業地域 & 1 & 1 & 0 & 0 \\
\hline 29. 商業地域 & 1 & 1 & 0 & 0 \\
\hline 30。商業地域 & 1 & 1 & 0 & 0 \\
\hline 33. 商業地域 & 1 & 1 & 0 & 0 \\
\hline 34. 住宅地域 & 2 & 1 & 1 & 1 \\
\hline 35. 混在地域 & 2 & 1 & 1 & 0 \\
\hline 36. 混在地域 & 2 & 1 & 1 & 0 \\
\hline 38. 住宅地域 & 3 & 1 & 1 & 1 \\
\hline 39. 混在地域 & 2 & 1 & 1 & 1 \\
\hline 41. 住宅地域 & 3 & 1 & 1 & 1 \\
\hline 42. 住宅地域 & 3 & 1 & 1 & 1 \\
\hline 44. 住宅地域 & 2 & 1 & 1 & 1 \\
\hline 45. 住宅地域 & 4 & 1 & 1 & 1 \\
\hline 合計壿入台数 (台) & $39(39 \mathrm{MW})$ & $20(40 \mathrm{MW})$ & $14(44 \mathrm{MW})$ & $11(44 \mathrm{MW})$ \\
\hline 合計節約率 $(\%)$ & 0.747 & 0.618 & 0.559 & 0.297 \\
\hline
\end{tabular}

〈4・3〉 複数台配置に基づく総導入容量の試算燃料 電池ユニットの総容量を，1〜4 MW と変化させた場合の 総導入台数を表 5 に示す。ただし, 燃料電池がより導入さ れやすい状況下で試算を行うために，表 2 における燃料電 池およびボイラの固定費を，各々 538.0 万円 $/ 100 \mathrm{~kW}$ 年 および 46,500円/Mcal·年に変更している。いずれの場合 も, 総導入容量は $40 \mathrm{MW}$ 程度であるが, 合計の節約率に は変化が見られ，ユニット容量の決定には十分な配慮が必 要であろう。熱負荷パターンについては，前述のように三 つのタイプを考えたが, 恒常的負荷を有する住宅地域に多 く導入されており，この結果からも開発アルゴリズムの妥 当性が理解される。

\section{5.あとがき}

本諭文では, 分散型電源の電力系統における導入傾向, および導入効果の詳細な解析を最終的な目的とし, 最適導 入計画決定手法について検討を加之た。電力供給の立場か らの配置決定手法に関する結果は，以下のとおりである。

（1）ペナルティファクタを指標とした優先順位決定法 による計算負担の軽減が妥当なことが，シミュレーション により確認された。

（2）しかし，電力供給のメリットのみでは，必ずしも 総コストを抑制できない場合があるう。

次に，熱併給を考慮した導入計画決定手法を提案した が，その特徵，および試算結果をまとると次のと扔りで ある。

（i）熱等価換算係数を定義し，その值を用いたコスト 算定法を提案した。なおがイラ固定費については，燃料費 計算の後その值を算定し加えており, 必ずしも全体の厳密
な最適化とはなっていない。

（ii）熱有効利用期待值と，ピーク時のペナルティファ クタの値を用いた候補母線選択により, 計算負担軽隇が可 能となった。

（iii）熱負荷の大きさについては，ュニット容量によら ず熱有効利用期待值がある程度大きくなければ，導入の経 済的メリットは隇少することとなろう。

今後, 更に多くの試算により詳細な検討を加え，また多 数のパラメー夕変更を想定したシミュレーションを実行 し，系統への分散型電源導入に対する指針を与えうるデー 夕を構築していきたい。

(平成 6 年 2 月 28 日受付)

\section{文献}

（1）豊田毫一・河野道信：「貯藏設硆を含む電源ベストミックスの決 定とその特徵」，電学論 $\mathrm{B}, \mathbf{1 0 6}, 279$ (昭 61-3)

（2）安田恵一郎・西谷健一・長谷川淳：「電力貯蔵システムを含む 各種電源のベストミックスならびに最適導入手順の決定」, 電学 諭 $\mathrm{B}, 108,569$ (昭 63-12)

(3) 諸住 哲・西谷健一・長谷川疩・藤原一：「䉓力系統に招け るエネルギー貯藏装置の最適配置に関する研究一経済運用から み大配置決定法一」, 電気学会電力技術研盗, PE-83-22(昭 58)

(4) O.I. Elgerd: ELECTRIC ENERGY SYSTEMS THEORY (1982) McGraw-Hill company

（5）芳賀善浩・北 裕幸・西谷健一・長谷川 疗・島津謙二・高橋広 文：「電力系統に招ける分散型電源配置・運用計画に関豆る基礎 的検討 $\rfloor,$ 電気学会電力技術研資, PE-91-100 (平 3)

\section{付 録}

\section{熱併給電源運用成立条件(18)式の導出}

ある $i$ 番目の分散電源の出力が $\Delta P_{c}(>0)$ だけ增加し, これに伴い対応するボイラの熱出力が $\Delta H_{B}$ だけ，更に各 発電機の出力が $\Delta P_{Y_{i}}(>0)$ だけ減少するものとする。この ときの需給バランス条件は,

$$
\Delta P_{c}-\sum_{j=1}^{N G} \Delta P_{T j}-\left(\frac{\partial P_{L}}{\partial P_{C}} \Delta P_{c}-\sum_{j=1}^{N G} \frac{\partial P_{L}}{\partial P_{T j}} \Delta P_{T j}\right)=0
$$

となり,これを整理すると，次式が得られる。

$$
\Delta P_{c}\left(1-\frac{\partial P_{L}}{\partial P_{c}}\right)=\sum_{j=1}^{N G} \Delta P_{T j}\left(1-\frac{\partial P_{L}}{\partial P_{T_{j}}}\right)
$$

また, 分散電源の出力増加にメリットがあるのは，コス 卜減分がコスト增分を上回わる，つまり次式が成立する場 合であるが，これは(17)式である。

$$
\sum_{j=1}^{N G} \Delta P_{T j} \frac{d f_{T j}}{d P_{T j}}>\frac{d f_{c}}{d P_{C}} \Delta P_{c}-\frac{d f_{B}}{d H_{B}} \Delta H_{B}
$$

いま，火力機は等 $\lambda$ 配分されており(12)式が満足されて いるものとすると，上式左辺は

$$
\text { (左辺) }=\lambda \sum_{j=1}^{N G} \Delta P_{T j}\left(1-\frac{\partial P_{L}}{\partial P_{T j}}\right)
$$

となる。一方(付 3) 式の右辺は，分散電源が熱的なメリッ 卜を有しているのは $H_{B}>0$ の場合であるから $\Delta H_{B}=\Delta H_{C}$, および(15)式を用い，次のと扔りとなる。

$$
\begin{aligned}
(\text { 右辺 }) & =\frac{d f_{c}}{d P_{c}} \Delta P_{c}-\mu_{i} \Delta H_{c} \\
& =\frac{d f_{c}}{d P_{c}} \Delta P_{c}-\mu_{i} \frac{d H_{c}}{d P_{c}} \Delta P_{c}
\end{aligned}
$$

（付 4) 式に(付 2) 式を代入し, 結局, 運用成立条件は次 
式で与えられる。

$$
\beta=\frac{\lambda}{L_{c}}+\mu_{i} \frac{d H_{c}}{d P_{c}}>\frac{d f_{c}}{d P_{c}}
$$

ここで， $L_{c}$ は分散電源が接続されている母線のペナルテ イファクタである。上式が等式で成立するとき最適条件が 得られることとなり，これが(13)式となる。また，熱的メ リットを考慮しない場合は $\mu_{i}=0$ であり，直ちに本文 $(3$ ) 式も理解される。

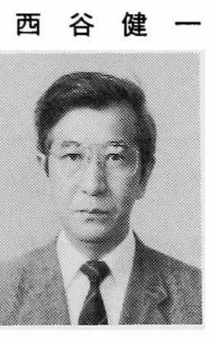

(正員) 1947 年 2 月 11 日生。1969 年 3 月北海 道大学理学部物理学科卒業。同年 4 月同大学工 学部電気工学科助手, 同助教授を経て, 1991 年 4 月北海道工業大学電気工学科教授, 現在に至 る。工学博士。電力系統工学, 特に電力系統状 態推定, 解析および運用・計画に関する研究に従 事。システム制御情報学会, エネルギー・資源学 会会員。

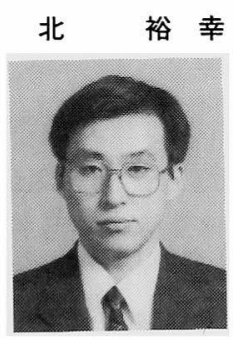

(正員) 1963 年 5 月 7 日生。 1988 年 3 月北海道 大学大学院工学研究科電気工学専攻修士課程修 了。同年 4 月同博士課程進学。1989 年 4 月同大 学工学部電気工学科助手, 現在に至る。工学博 士。主として, 電力系統の解析・制御に関する研 究に従事。

長谷川

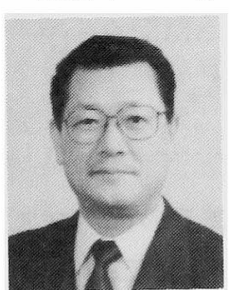

（正員） 1943 年 12 月 13 日生。1971 年 3 月北海 道大学大学院工学研究科電気工学専攻博士課程 修了。同年 4 月同大学工学部講師, 同助教授を 経て, 1985 年 4 月同教授, 現在に至る。工学博 士。主として, 電力系統の計画・運用・制御・解 析，およびエネルギー貯蔵に関する研究に従事。 IEEE, 日本 OR 学会, 照明学会, エネルギー・ 資源学会, 低温工学協会会員。
芳 賀 善 浩 （正員） 1968 年 3 月 23 日生。1992 年 3 月北海 道大学大学院工学研究科電気工学専攻修士課程 修了。同年 4 月北海道旅客鉄道 (株) 入社, 現在 に至る。在学中, 主として電力系統運用・計画に 関する研究に従事。

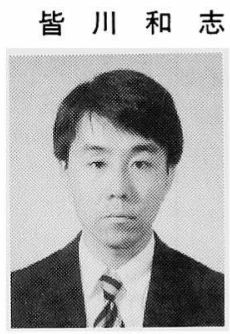

（正員） 1985 年 3 月北海道大学大学院工学研究 科電気工学専攻修士課程修了。同年 4 月北海道 電力 (株) 入社。電力系統運用・解析業務を経て, 現在, 同社総合研究所研究企画グループ。

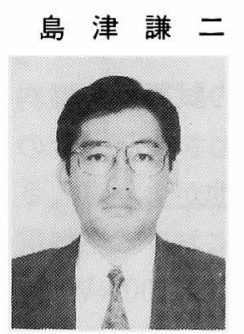

(非会員) 1980 年 3 月武蔵工業大学機械工学科 卒業。同年 4 月北海道電力 (株) 入社。火力発電 所の運転・保修業務を経て燃料電池の研究開発に 従事。現在, 同社総合研究所新エネ・新素材グル ープ主査研究員。

中 村 英 男 (非会員) 1972 年 3 月北海道大学工学部機械工 学第二学科卒業。同年 4 月北海道電力 (株) 入社。 火力部門の計画・運用業務, 新エネ・新素材の研 究開発業務を経て, 現在, 同社火力部火力運営 グループリーダ。

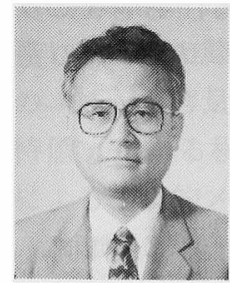

